\title{
편두통의 약물요법
}

\section{Drug Therapy for Migraine}

\author{
정 진 상 | 성균관의대 신경과 | Chin-Sang Chung, MD \\ Department of Neurology, Sungkyunkwan University School of Medicine \\ E-mail : cschung@smc.samsung.co.kr
}

J Korean Med Assoc 2007; 50(I0): 917 - 923

\section{Abstract}

\begin{abstract}
igraine significantly disturbs the quality of life of the patients by causing severe throbbing headache associated with neurological, autonomic, and gastrointestinal symptoms. Management of migraine starts from the correct diagnosis based on the classification proposed by the International Headache Society in 2004. Treatment failure and medication overuse and abuse commonly result from misdiagnosis of specific type of headache. Treatment includes: (1) nonpharmacological therapy (patient education, regular exercise, abstinence of caffeine and alcohol drinking, avoidance of fasting, and regular sleep), (2) acute pharmacological therapy (simple analgesics, NSAIDs, ergotamines, triptans, etc.), and (3) prophylactic pharmacological therapy ( $\beta$ blockers, calcium channel blockers, antidepressants, and anticonvulsants). Because individual drugs have their unique properties and drug interactions, careful selection and combination of the drugs must be made on the basis of the patient's migraine type, associated symptoms, and comorbidities. One of the complications of migraine drug therapy is transformation of episodic migraine into chronic daily headache that is caused by abuse or overuse of anti-migraine drugs. So the correct diagnosis of migraine and appropriate pharmacological and non-pharmacological treatments are of utmost importance in improving the patient's quality of life and prevention of medication-overuse headache.
\end{abstract}

Keywords : Migraine; Nonpharmacological therapy; Acute abortive therapy; Triptans; Prophylctic therapy

핵 심 용 어: 편두통; 비약물요법; 급성기요법; 트립탄제; 예방요법

서 론

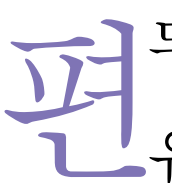
두통은 어느 나라건 전 인구의 $10 \%$ 이상이 않고 있는 유병률이 높은 질환이다. 생활에 지장을 초래할 정도 로 심한 두통 자체의 통증 때문에도 고통스럽지만 동반되는 다양한 신경과적 증상과 위장장애 때문에 편두통 환자들의 삶의 질은 현저하게 나빠진다. 주로 한쪽 머리에 발생하는
박동성 두통은 일단 발생하면 하루이틀 정도 지속되고 몇 차례씩 반복해서 나타날 수 있다. 두통발작 중에는 일상적 인 움직임에 의해서도 두통이 악화되고 구역, 구토, 빛 혐오 증, 소리 혐오증, 냄새 혐오증 등을 동반함으로써 정상적인 생활이 불가능하게 된다.

따라서 편두통 발작의 효과적인 치료와 예방은 환자들의 삶의 질을 크게 개선할 수 있다. 


\section{편두통 발생기전}

편두통이 생기는 정확한 원인은 밝혀져 있지 않지만 편두 통 발작 기전을 간단하게 설명하면 다음과 같다. 기본적으 로 편두통 환자는 정상인의 뇌에 비하여 쉽게 흥분할 수 있 는 소위 "예민한 뇌" 를 가지고 있는데 갑작스러운 신체 내 부 또는 외부환경의 변화에 의해 뇌가 자극되어 흥분하면 이에 뇌혈관이 팽창하고 이에 따라 삼차 신경계가 자극되면 서 뇌간 및 대뇌의 통증체계가 흥분하면서 두통이 발생하고 신경 증상 및 자율신경 증상이 수반된다. 시야장애와 같은 편두통의 조짐 현상은 후두엽의 뇌혈류량이 떨어져 뇌세포 의 대사가 감소되어 나타나며 그 이후 뇌혈관의 확장과 주 위의 염증에 의해 통증이 발생한다. serotonin과 같은 신경 전달물질이 이러한 통증 발생에 중요한 역할을 한다.

\section{편두통의 진단기준과 정확한 편두통 진단의 중요성}

편두통은 주 증상 및 동반되는 증상에 따라 15 개의 아유 형으로 나눌 수 있을 정도로 다양한 임상양상을 보이기 때문 에 진단이 쉽지 않다. 세계적으로 국제두통학회에서 2004년 에 개정한 분류법과 진단기준(Table 1)을 공통적으로 사용 하고 있다. 따라서 모든 환자에 대하여 이를 토대로 정확하 게 진단하고 치료해야 한다.

\section{편두통의 치료}

\section{1. 비약물요법}

편두통은 약물을 사용하지 않고도 어느 정도 완화 또는 예방할 수 있다. 우선 환자에게 편두통이란 어떤 질환인지, 유발요인의 역할, 치료원칙, 자연 경과, 치료적 생활습관의 중요성 등을 교육한다. 그리고 두통일기를 기록해 유발요인 을 파악하고 유발요인을 제거하거나 회피하도록 하며 치료 에 대한 반응이나 경과를 기록하게 한다. 유발인자로는 스 트레스, 특정음식, 강렬한 빛이나 시끄러운 소리, 향수나 담 배 냄새, 월경, 날씨 변화, 수면부족이나 과잉수면, 결식 등
Table 1. Diagnostic criteria of migraine

1) At least 5 attacks fulfilling criteria $B \sim D$

2) Headache attacks lasting $4 \sim 72$ hours (untreated or unsuccessfully treated)

3) Headache has at least two of the following characteristics:

- unilateral location

- pulsating quality

- moderate or severe pain intensity

- aggravation by or causing avoidance of routine physical activity (eg, walking or climbing stairs)

4) During headache at least one of the following:

- nausea and/or vomiting

- photophobia and phonophobia

5) Not attributed to another disorder

이 있다. 편두통을 잘 유발하는 음식물로는 tyramine이 포 함된 치즈, 쵸콜렛, 커피, 알코올 중에 붉은색 포도주, 우유 제품, 견과(호두, 밤 따위), 소금, 토마토, 코코넛, 음식 첨가 물인 monosodium glutamate (MSG)가 포함된 중국음식 등이다. 따라서 빠르고 건강한 스트레스 완화방법의 습득, 규칙적인 수면습관, 카페인 음료의 중단, 규칙적인 운동, 규 칙적인 식사, 금주 등 치료적 생활습관을 들일 수 있도록 격 려해야 한다. 그러나 비약물적 방법만으로는 편두통 발생 을 완전히 막지는 못하기 때문에 약물요법이 필요한 경우 가 많다.

\section{2. 급성 편두통의 약물요법}

편두통이 발작하면 최대한 빨리 두통과 동반증상들을 멈 추게 하거나 심한 두통으로 진행하지 못하도록 치료해야 한 다. 일단 선택한 치료제는 용량을 충분히 사용하며 중도에 포기하지 않는다. 약물은 편두통 유형, 두통의 심한 정도, 구 역과 구토 같은 동반증상 유무, 이전에 사용했던 치료제의 효과와 부작용, 그리고 금기사항이나 동반질환 유무 등을 고려해 선택한다.

편두통 발작이 가볍거나 과거에 약물로 효과를 본 적이 있다면 처방 없이 구할 수 있는 단순진통제나 복합진통제를 사용할 수 있다. NSAID나 복합진통제에 반응하지 않는 경 우에는 triptan이나 ergotamine제와 같은 편두통 특이성 약제들을 사용한다. 편두통에 동반되는 구역이나 구토 증세 가 심할 경우 항구토제를 사용하고 편두통 약물을 주사제로 


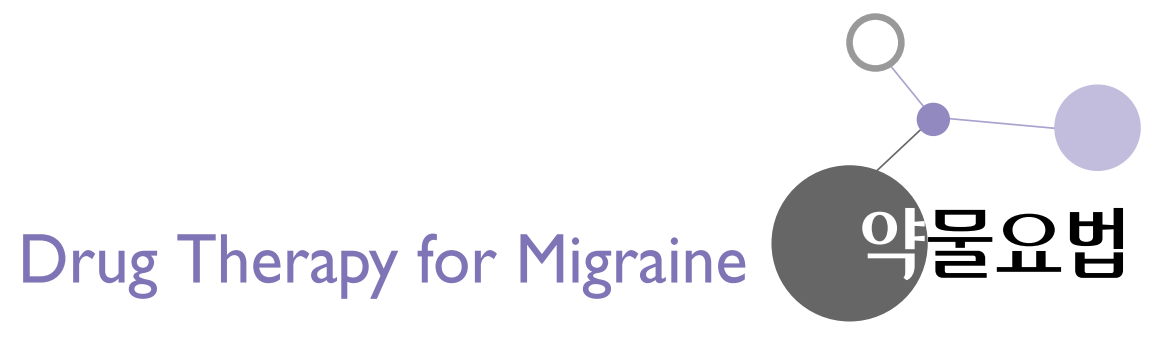

사용한다. 급성기 약물 투여는 1주에 2회 이하로 제한함으 로써 약물과용두통(medication overuse headache, $\mathrm{MOH}$ ) 으로 전환되는 것을 막고 그 이상 잦은 경우 예방요법을 시 작한다.

(1) 비특이적 급성기 약물

단순진통제인 aspirin은 경도나 중등도의 편두통 치료에 사용하며 1회 500 1,000mg을 투여할 수 있으며 1일 최대 $4,000 \mathrm{mg}$ 이하, 1 주에 3 일 이내로 복용횟수를 제한한다. Metoclopramide나 caffeine과 함께 투여하면 더 효과적이 며 장기간 복용하면 위궤양이나 위장관출혈, 구역 등이 있다.

Acetaminophen 역시 경도나 중등도의 편두통발작 치료 에 쓰인다. 1 회 투여량은 500 1,000mg이며 1일 4,000mg 이하, 그리고 1주일에 3 일 이내로 제한한다. Metoclopramide와 caffeine 등을 병용하면 더 효과적이다. 대사산물 로 인해 신장 기능에 이상을 초래할 수 있으나 소화기계 부 작용은 aspirin보다 적다.

NSAID인 naproxen과 ibuprofen은 경구로 투여하면 1 2시간 뒤에 최고 혈중농도에 도달하며 ketorolac은 경구제 도 있지만 주사제가 있기 때문에 근육주사를 함으로써 빠른 효과를 볼 수 있다. NSAID는 소화불량, 속쓰림, 설사, 변비, 구역, 구토, 이명, 어지러움 등을 일으킬 수 있으며 장기간 복용하면 위궤양같은 위장관 부작용이 생길 수 있다.

Caffeine은 커피나 콜라같은 음료와 비처방 복합두통약 대부분에 포함되어 있어 편두통 환자들이 가장 남용하기 쉬 운 물질이다. 실제 단순진통제만 단독으로 투여할 때보다 caffeine을 혼합하면 더 효과적이다. 그러나 오래 동안 caffeine을 과용한 환자는 caffeine 자체로 인해서 편두통이 악 화되거나 새로운 형태의 혈관성 두통이 생길 수도 있으며 혈관수축제의 효과를 떨어뜨리므로 치료를 시작하기 전에 반드시 중단해야 한다. 그러나 금단증상으로 심한 반동두 통, 구역, 구토 등이 처음 1 주일 정도 발생할 수 있으므로 사 전에 충분히 설명해야 한다.

혈관수축제 isomepheptane과 진정제 dichloralphenazone이 포함되어 있는 Midrin은 비교적 심하지 않은 편두통 발작에 효과적이지만 장기간 반복 투여시 반동두통을 유발 할 수 있으므로 1 주일에 2 일 이내로 투여를 제한해야 한다.
편두통발작 때에는 위장관의 운동성이 감소하면서 식욕 감퇴, 구역, 구토 등이 나타나며 약물흡수도 저하되므로 급 성기 약물의 치료효과가 떨어진다. 따라서 metoclopramide나 domperidone같은 항구토제를 함께 쓰면 구역과 구토를 줄일 뿐만 아니라 약물흡수를 향상시킬 수 있다. Metoclopramide는 dopamine 대항제이며 serotonin 작 용제로서 직접 두통을 호전시키는 작용도 있는데 경구투여, 정맥주사, 근육주사가 가능하며 장기간 과량 사용시 파라미 드외증상이 나타날 수 있다.

\section{(2) Ergotamine제}

Ergotamine제로는 ergotamine과 dihydroergotamine (DHE)이 있다. Ergotamine은 serotonin 수용체인 $5-\mathrm{HT}_{1}$ 수용체와 $5-\mathrm{HT}_{2}$ 수용체에 작용해 혈관을 수축시키고 경막 의 신경탓염증을 억제한다. Ergotamine은 보통 caffeine과 의 복합제로 사용하는데 경구투여시 흡수가 느리고 구역, 구토, 복통, 손저림, 설사가 수반될 수 있기 때문에 싫어하는 환자도 종종 있으나 편두통 환자들에게 비교적 안전하면서 도 효과가 좋은 약물이다.

그러나 ergotamine은 남용하면 약물과용두통으로 진행 하므로 1 주에 2 회 이내로 제한해야 한다. DHE는 ergotamine의 구조를 일부 변형한 약물로서 혈관수축 작용은 적 으며 항구토효과가 있어 ergotamine보다는 구역이나 구토 가 드물고 반동성 두통도 거의 없다. 또한 정맥주사나 비강 흡입제가 있어 급성기에 구토가 심한 환자에게 유리하다. 그러나 현재 한국에서는 DHE가 판매되고 있지 않다. 주의 해야 할 사항은 ergotamine제는 혈관수축작용과 평활근 수 축작용이 있으므로 말초혈관질환, 관동맥질환, 신장 또는 간기능 이상, 임신, 조절되지 않는 고혈압이 있는 환자들에 게는 사용하지 않는 것이 좋다.

(3) Triptan제

Triptan제는 serotonin수용체인 5- $\mathrm{HT}_{1 \mathrm{~B} / \mathrm{D}}$ 수용체에 선 택적으로 작용하여 활성화된 3 차 신경혈관계 때문에 생긴 현 상들을 차단하거나 역전시킴으로써 편두통 발작을 완화시킨 다. 현재까지 sumatriptan, zolmitriptan, naratriptan, rizatriptan, eletriptan, frovatriptan, almotriptan 등이 임 상에서 사용되고 있으며 한국에는 sumatriptan, zolmitrip- 
Table 2. Pharmacokinetic properties of triptans

\begin{tabular}{llllllll}
\hline Triptans & Suma- & Nara - & Zolmi- & Almo- & Riza- & Ele- & Frova- \\
\hline Half-life (hr) & 2.0 & $5.0 \sim 6.3$ & 3.0 & 3.5 & 2.0 & 5.0 & 25.0 \\
Tmax-ictal (hr) & 2.5 & - & 4.0 & $2.0 \sim 3.0$ & 1.0 & 2.8 & 3.0 \\
Tmax-interictal (hr) & 2.0 & $2.0 \sim 3.0$ & $1.8 \sim 2.5$ & $1.4 \sim 3.8$ & 1.0 & $1.4 \sim 1.8$ & 3.0 \\
Oral bioavailability (\%) & 14 & $63 \sim 74$ & 40 & 69 & 40 & 50 & $24 \sim 30$ \\
Availability in Korean market (2007) & Yes & Yes & Yes & Phase 3 trial finished & Phase 3 trial finished & No & No \\
\hline
\end{tabular}

$\tan$, naratriptan만이 현재 처방 가능하다. 이들의 약리학적 작용기전은 비슷하지만 각각 독특한 약리학적 특성을 갖고 있어 장단점이 조금씩 다르므로 이를 감안해 환자의 편두통 특징에 따라 약제를 선택한다(Table 2). Tmax (혈장 최고 농도에 이르는 시간)가 짧을수록 효과가 빨리 나타나고 더 효과적이며 반감기가 길수록 발작 완화 후 증상의 재발이 더 적다.

Triptan제는 모두 5- $\mathrm{HT}_{1 \mathrm{~B} / 1 \mathrm{D}}$ 에 특이하게 작용하기 때문 에 다른 비특이적 편두통 약물에 비해 전신적인 부작용이 적다. 그러나 박동치는 느낌, 저림, 이상한 느낌, 가슴 또는 흥부의 압박감, 열감, 타는 듯한 느낌, 차가운 느낌 등의 다 양한 감각이상 증상, 구역, 어지러움, 졸음, 피로감 등이 일 시적으로 나타날 수 있다. 그리고 triptan제는 심장동맥을 수축시킬 수 있기 때문에 심근경색이나 협심증과 같은 심혈 관질환이 있는 사람에게는 투약하지 않는다. 관동맥질환의 위험도를 높이는 당뇨병, 고혈압, 고지혈증, 관동맥질환의 가족력, 흡연자 등이 있는 환자에게는 사용을 자제하는 것 이 안전하다.

Sumatriptan은 최초로 개발된 triptan제로서 효과가 빨 리 나타나므로 두통 발생 즉시 투여하면 좋은 치료효과를 볼 수 있다. 두통 뿐만 아니라 구역, 구토, 빛공포증, 소리 공 포증, 냄새 공포증같은 동반증상들도 호전시킨다. 처음에는 피하주사제로 개발되었으나 부작용의 발현이 잦고 심하게 나타나 현재에는 경구제와 비강내투여제 등 다양한 경로로 도 투약할 수 있게 개발되어 있다. 한국에서는 현재 경구제 만 처방 가능하다. 구역이나 구토가 심하거나 빠른 효과를 기대하는 경우에는 피하주사나 비강투여제가 더 효과적이 다. 편두통 예방약물인 verapamil, amitriptyline, propranolol과 같은 약제들과는 특별한 약물상호작용이 없다.
Ergotamine제를 같이 사용하거나 짧은 간격을 두고 사용하 면 혈관수축이 심하게 나타날 수 있으므로 중복 투여하지 않는 것 좋다.

그리고 triptan제를 항우울제인 선택적 serotonin 재흡수 억제제(selective serotonin reuptake inhi-bitor, SSRI)를 사용하는 환자에게 투여하는 경우 마비, 과다반사, 실조, 빈 맥, 떨림, 발한, 안절부절 못함 등의 serotonin 증후군이 생 길 수 있으므로 주의해야 한다. 급성기 편두통약물은 과용 시 $\mathrm{MOH}$ 가 될 수 있으므로 단순진통제나 NSAID는 1주일 에 3 일 이내로, 정온제를 포함한 복합진통제, triptan제, ergotamine제 등은 1주일에 2일 이내로 제한한다.

\section{3. 예방치료}

예방요법은 편두통 환자의 예민한 뇌와 혈관의 흥분성을 낮추어 편두통 발작에 대한 역치를 높임으로써 겉질확산성 억제(cortical spreading depression, CSD)의 발생을 방지 하고 신경계를 안정화시키고 삼차신경혈관계가 활성화되는 것을 막고 항통증계를 강화시키며 신경탓염증을 차단하고 중추성 민감화(central sensitization)를 방지한다. 이러한 작용기전을 통해 편두통 발작의 횟수, 통증의 강도, 기간을 감소시키고 급성기 약물에 대한 반응을 개선하고 환자들의 삶의 질을 향상시킨다.

장기적인 예방요법은

(1) 편두통 발작이 1 주일에 3 회 이상 자주 나타나는 경우

(2) 급성기 치료를 해도 일상생활에 지장을 많이 받는 경우

(3) 급성기 대증요법이 효과가 없거나 약물을 과용하는 경우

(4) 급성기 약물을 부작용 때문에 사용할 수 없는 경우

(5) 편마비성 편두통, 기저형편두통, 지속성조짐편두통, 


\section{Drug Therapy for Migraine \\ 약물요법}

망막편두통, 편두통뇌경색증 등과 같이 국소적 뇌합 병증을 초래할 수 있는 경우에 시작한다.

대부분의 편두통 예방약물은 3 4주 정도는 지나야 예방 효과가 나타나므로 환자와 의사 모두 인내심을 갖고 기다려 야 한다. 일반적으로 두통과 같은 통증에 대한 기억에는 한 계가 있기 때문에 반드시 두통일기를 기록하면서 임상경과 를 관찰하는 것이 필요하다. 만족할만한 치료효과를 보이는 용량에 다다르면 이를 유지용량으로 6개월 정도 지속하다 가 서서히 용량을 줄여가면서 약물중단을 시도해 보는데 대 부분 약을 성공적으로 중단할 수 있다. 그러나 일부 환자는 효과를 보지 못하고 계속 약물을 복용해야 하는데 반드시 환자가 비약물요법도 잘 지키고 있는지 확인할 필요가 있 다. 많이 사용되는 편두통 예방제로는 베타차단제, 칼슘통 로차단제, 항우울제, 항경련제, NSAID 등이 있다.

월경편두통, 조짐 증상이 지속적으로 나타나는 편두통, 미리 예상할 수 있는 상황으로 인해 유발되는 편두통 발작 을 예방할 때는 발작이 예상되는 기간에 며칠 동안만 예방 약물을 사용하고 중단하는 단기예방요법을 사용한다. 이 때는 진통제나 혈관수축제같은 급성기 약물을 같이 쓸 수 있다.

\section{(1) $\beta$ 차단제}

$\beta$ 차단제는 중추성 $\beta$ 수용체를 억제하여 교감신경계의 활 성을 억제하고 serotonin 수용체에 작용하는 것으로 추정 된다. 편두통 예방 목적으로 사용하는 $\beta$ 차단제 로는 propranolol, atenolol, timolol 등이 있다. 고혈압, 손떨림, 불 안, 공황장애가 있는 환자에게 특히 유용하다. 임상의들이 가장 많이 처방하는 propranolol은 반감기가 4 6시간으로 짧으며 대개 1일 40mg에서 시작하여 통상 1 일 80 160mg 정도를 유지한다. $\beta$ 차단제의 부작용으로는 피로, 우울증, 구 역, 어지러움, 기립저혈압, 서맥 등이 있다. 천식, 당뇨병, Raynaud병, 울혈성 심부전 등이 있는 환자에서는 사용하지 않는다. Verapamil과 병용하는 경우에는 동방결절기능부 전증(sick sinus syndrome)이 발생할 수 있으므로 병용하 지 않는다. $\beta$ 차단제를 갑자기 중단하면 두통, 떨림이 있을 수 있으므로 서서히 감량한다.

\section{(2) 칼슘통로차단제 (calcium channel blocker, CCB)}

편두통 예방효과를 가진 CCB에는 verapamil, flunarizine 등이 있으며 작용기전은 확실하게 밝혀져 있지 않다. Verapamil은 1일 $80 \mathrm{mg}$ 으로 시작하여 보통 1일 80 $360 \mathrm{mg}$ 으로 유지한다. 흔한 부작용으로는 변비, 어지러움, 구역, 저혈압, 두통 등이 있다. 앞에서 설명한 것처럼 propranolol을 함께 사용하면 동방결절기능부전증의 위험이 있다. Flunarizine은 1일 5 10mg 사용하며 부작용으로 체 중 증가, 졸림, 구강건조, 어지러움, 저혈압 등이 나타날 수 있는데 장기간 투여하면 약물유발 파킨슨 증후군같은 피라 미드외 징후를 유발할 수 있으므로 진료시 매번 확인하고 보 행이 느려지거나 손떨림 증상이 있으며 즉시 중단해야 한다.

\section{(3) 항우울제}

우울증이 있는 편두통 환자에게는 항우울제를 최우선적 으로 선택하지만 우울증이 없는 경우에도 편두통 발작 예방 을 위해 사용할 수 있다. 삼환계항우울제, SSRI, serotoninnorepinephrine 재흡수억제제(serotonin-norepinephrine reuptake inhibitor, SNRI) 등이 모두 편두통 예방효과가 있 다. 삼환계항우울제 중에는 amitriptyline과 nortriptyline 을 가장 많이 처방하는데 통상 우울증 치료목적으로 사용하 는 용량보다 훨씬 적은 용량에서 효과를 보인다. Amitriptyline은 1 일 $10 \sim 25 \mathrm{mg}$ 에서 시작하여 증량하는데 $100 \mathrm{mg}$ 이상 사용해야 하는 경우는 드물다. 흔한 부작용으로는 구 강건조, 인지기능이상, 구역, 서맥, 체중 증가 등이 있으며 진정효과가 있으므로 취침 전에 투여하는 것이 바람직하다. Nortriptyline은 amitriptyline보다 진정효과가 덜하며 취침 시 10 25mg으로 시작한다. SSRI는 삼환계항우울제에 비해 진정효과 및 심혈관계 부작용이 적은데 fluoxetine, fluvoxamine, paroxetine, sertraline 등이 편두통 예방목적 으로 처방할 수 있는 약제이다. 흔한 부작용으로는 안절부 절못함, 불면, 신경질, 피로, 떨림 등이 있다. 현재 이 약제들 은 한국에서는 정신과 전문의가 아니면 60 일 이상 처방할 수 없도록 제한하고 있어 편두통 예방 목적으로 장기간 처 방하는 데는 한계가 있다.

\section{(4) 항경련제}

편두통 예방효과가 입증된 항경련제로는 valproate와 
topiramate가 대표적이다. Valproate는 항경련 목적으로 쓰는 용량보다 적은 1일 100 1,000mg에서 효과를 보인다. 부작용으로 구역, 피로, 손떨림, 체중 증가, 어지럼, 탈모 등 이 있기 때문에 젊은 여성 환자들에게 사용할 때는 주의가 필요하다. Topiramate도 항경련용량보다 적은 1일 25 $100 \mathrm{mg}$ 정도에서 편두통 예방효과가 있다. 흔한 부작용으 로는 투약 초기에 손발저림, 식욕감퇴, 기억장애 등의 인지 기능장애가 나타날 수 있으며 장기간 투여하는 경우 체중 감소와 신장결석 등이 생길 수 있다. 손발저림 증상은 투여 환자의 약 $50 \%$ 에서 나타나며 수 주간 지속되다가 사라지는 경우가 대부분이지만 계속되는 경우 용량을 줄이거나 칼륨 제를 추가로 처방한다. 체중 감소는 $100 \mathrm{mg}$ 투여시에 평균 체중의 3 5\% 정도 감소하기 때문에 비만이 있는 환자나 전 에 다른 편두통 예방제를 사용함으로써 체중 증가가 있었 던 환자에게 투여할 수 있다. 상기 두 약제 외에 현재 zonisamide와 levetiracetam이 현재 임상시험 중에 있다. 이 외에도 botulinum toxin, riboflavin, co-enzyme Q10, 고혈압 약물인 candesartan과 lisinopril이 무작위대조 이중 맹검연구에서 편두통 예방효과가 있는 것으로 보고되었다.

(5) 예방약물의 병용

단독요법으로 예방효과가 없거나 충분하지 않을 경우에 는 일단 타 약제로 교체하고, 그래도 안되는 경우 2 가지 이 상의 예방약물을 병용할 수 있다. 주의해야 할 사항은 SSRI 와 삼환계항우울제를 병용하면 경련의 위험이 높아지고 고 혈압도 유발할 수 있다. Fluoxetin과 $\beta$ 차단제는 저혈압을 일으킬 위험이 있다. 앞에서 설명한 바와 같이 verapamil과 $\beta$ 차단제(특히 propranolol)를 병용하면 동방결절기능부전 증을 유발할 수 있기 때문에 병용해선 안된다. 그리고 항우 울제는 MAO 억제제와 SSRI나 삼환계항우울제를 병용하면 체내의 serotonin 의 증가를 유발하여 serotonin 증후군을 유발할 수 있다.
편두통은 유병률이 높으면서 삶의 질을 나쁘게 하는 질환 이지만 정확한 진단을 하고 적절한 치료와 예방을 한다면 환자의 삶의 질을 현저하게 좋게 할 수 있다. 반면 정확한 진 단을 내리지 않으면 약물남용이나 과용으로 이어지면서 난 치성 두통이 될 수 있다. 편두통 치료에는 일차적으로 건강 한 생활습관을 지키고 유발요인을 제거하는 비약물요법이 있으며 약물요법으로는 급성 발작에 대한 대증요법과 잦은 발작 횟수와 급성 약물반응을 좋게 하는 예방요법이 있다. 정확한 진단을 토대로 적절한 치료를 시행한다면 편두통의 심한 통증과 동반되는 증상으로부터 해방시킴으로써 삶의 질을 높이고 난치성 두통으로 전환되는 것을 막을 수 있다.

\section{참고문헌}

1. Bigal ME, Rapoport AM, Sheftell FD, Tepper SJ, Lipton RB. Transformed migraine and medication overuse in a tertiary headache centre-clinical characteristics and treatment outcomes. Cephalalgia 2004; 24: 483-490.

2. Ferrari A, Sternieri E, Ferraris E, Bertolini A. Emerging problems in the pharmacology of migraine: interactions between triptans and drugs for prophylaxis. Pharmacol Res 2003; 48: 1-9.

3. Goadsby PJ, Lipton RB, Ferrari MD. Migraine. Current understanding and treatment. N Engl J Med 2002; 346: 257-270.

4. Headache Classification Subcommittee of the International Headache Society. The International Classification of Headache Disorders. $2^{\text {nd }}$ ed. Cephalalgia 2004; 24(S1): 8-160.

5. Landy SH, Lobo BL. Migraine treatment throughout the lifecycle. Expert Rev Neurotherapeutics 2005; 5: 343-353.

6. Loder E, Biondi D. General principles of migraine management. The changing role of prevention. Headache 2005; 45 (S1): 33-47.

7. Silberstein SD, Goadsby PJ. Migraine: preventive treatment. Cephalalgia 2002; 22: 491-512. 
Peer Reviewer Commentary

\section{김 병 건 (을지의대 신경과)}

편두통은 긴장형 두통보다 유병률은 낮지만 통증의 강도가 휠씬 더 심하고 오심, 구토 등이 동반되기 때문에 신경과 외 래를 찾는 가장 흔한 질환이다. 특히 사회활동 및 생산성이 높은 연령에서 유병률이 높아 편두통은 개인적 측면 이외에 도 사회 경제적으로 상당한 부담을 준다. 본 논문에서는 편두통의 최신 병리기전 및 진단기준에 대한 간단한 소개와 비 약물적 및 약물적 치료의 선택기준과 부작용에 대하여 자세히 기술하고 있다. 필자는 편두통을 적절히 치료하기 위해서 는 정확히 진단이 선행되어야 하며 무분별한 진통제의 사용은 난치성 두통의 주요한 원인이 될 수 있다는 점을 강조하 였다. 이울러 편두통 치료에는 1차적으로 유발요인을 제거하는 비약물요법이 선택되어야 하며 예방약제의 선택에는 약 제의 부작용과 환자의 동반 이환질환 등을 고려해야 함을 강조하였다.

\section{정 재 면 (인제의대 신경과)}

본 논문은 최근 그 기전이 밝혀지고 있으며, 이에 따라 특이약물이 속속 개발되고 있는 편두통의 치료에 관해 매우 명 료하게 기술하고 있다. 고전적인 치료 약제들의 편두통에 대한 용법 뿐 아니라 새롭게 개발되어 점차 그 사용빈도가 증 가하고 있는 급성기 및 예방치료 약제에 대해 실제적인 임상적용 방법을 조망하고 있다. 신경과 전문의가 아닌 모든 의 사들이 반드시 일독해야 할 논문이라고 생각한다. 특히 편두통의 적절한 치료를 위해서는 정확한 진단이 전제가 되어야 하며 약물의 오남용으로 인해 만성 난치성 두통으로 진행한다는 점을 강조한 것은 공감하는 바가 크다. 